Florida International University FIU Digital Commons

FIU Electronic Theses and Dissertations

University Graduate School

3-26-2014

\title{
Mothers and their Children: Harry Potter and Melanie Klein
}

Kristina Mur

ksanc004@fiu.edu

DOI: $10.25148 /$ etd.FI14040843

Follow this and additional works at: https://digitalcommons.fiu.edu/etd

Part of the Developmental Psychology Commons, Literature in English, British Isles Commons, and the Modern Literature Commons

\section{Recommended Citation}

Mur, Kristina, "Mothers and their Children: Harry Potter and Melanie Klein" (2014). FIU Electronic Theses and Dissertations. 1268. https://digitalcommons.fiu.edu/etd/1268

This work is brought to you for free and open access by the University Graduate School at FIU Digital Commons. It has been accepted for inclusion in FIU Electronic Theses and Dissertations by an authorized administrator of FIU Digital Commons. For more information, please contact dcc@fiu.edu. 


\title{
FLORIDA INTERNATIONAL UNIVERSITY
}

\author{
Miami, Florida
}

\section{MOTHERS AND THEIR CHILDREN: HARRY POTTER AND MELANIE KLEIN}

\author{
A thesis submitted in partial fulfillment of \\ the requirements for the degree of \\ MASTER OF ARTS \\ in \\ ENGLISH \\ by \\ Kristina Mur
}


To: Dean Kenneth G. Furton

College of Arts and Sciences

This thesis, written by Kristina Mur, and entitled Mothers and their Children: Harry Potter and Melanie Klein, having been approved in respect to style and intellectual content, is referred to you for judgment.

We have read this thesis and recommend that it be approved.

Bruce Harvey

Paul Gillespie

Andrew Strycharski, Major Professor

Date of Defense: March 26, 2014

The thesis of Kristina Mur is approved.

Dean Kenneth G. Furton

College of Arts and Sciences

Dean Lakshmi N. Reddi

University Graduate School

Florida International University, 2014 
(C) Copyright 2014 by Kristina Mur

All rights reserved. 


\section{ACKNOWLEDGMENTS}

I would first like to thank my thesis director, Andrew Strycharski who accepted my need to write on Harry Potter and guided my thesis with patience

for four years. And thank you to Bruce Harvey and Paula Gillespie who signed on to help me get through this.

Thank you to my husband, Chris, and mother, Isabel, who knew when to ask and not to ask me about the process and understood it would only get done when I was ready.

I would also like to thank my sister Lyssa and nephews who helped me locate important quotes.

And thank you to my sister Marlene and coworker Sissi who read my entire thesis for editing purposes; it was a tremendous help. 


\section{ABSTRACT OF THE THESIS \\ MOTHERS AND THEIR CHILDREN: HARRY POTTER AND MELANIE KLEIN by}

Kristina Mur

Florida International University, 2014

Miami, Florida

Professor Andrew Strycharski, Major Professor

This thesis analyzes the mother-child relationship in the Harry Potter novels by using Melanie Klein's object-relation based theory. I argue the mothers and their relationship with their offspring represent fragments of a whole complicated psyche. The characters are not analyzed as individuals, but instead as pieces, sometimes multiple pieces, of a whole psyche. When these characters and novels are taken together, a whole, multi-faceted person comes into view. Rowling depicts both good and bad mothers, and children who characterize different positions according to Klein. These positions are the paranoid-schizoid position with Harry Potter and the depressive position with Sirius Black and Rubeus Hagrid. Although the series suggests a developmental arc or a coming of age story within fantasy literature, there is no linear progression; instead, there are disruptive positions without development. 


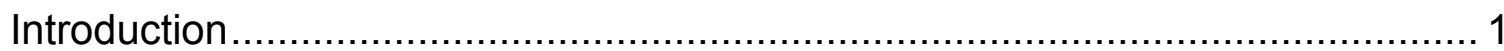

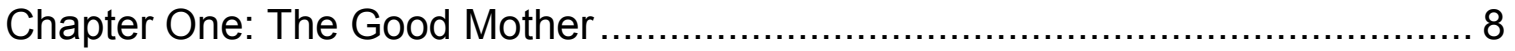

I. Lily Potter: the Idealized Mother ....................................................... 8

II. Molly Weasley: the Real, Whole Mother ............................................ 17

III. Narcissa Malfoy: Good Mother Transcending Evil ............................... 21

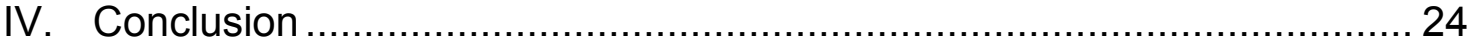

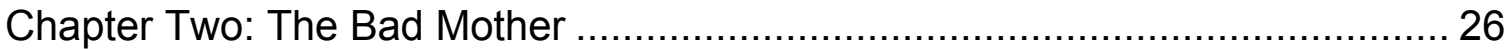

I. Mrs. Black: the Bad Mother.......................................................... 28

II. Hagrid and the Absent Mother ........................................................... 31

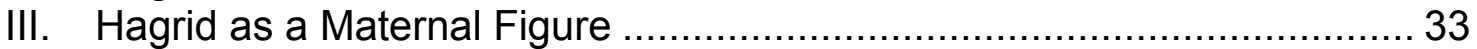

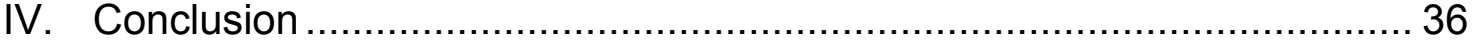

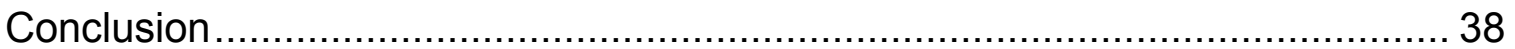

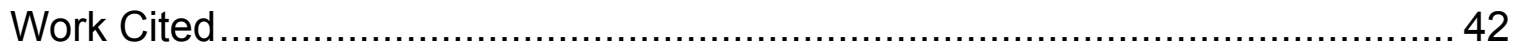




\section{ABBREVIATIONS AND ACRONOYMS}

SS - Harry Potter and the Sorcerer's Stone

CS - Harry Potter and the Chamber of Secrets

PA - Harry Potter and the Prisoner of Azkaban

GF - Harry Potter and the Goblet of Fire

OP - Harry Potter and the Order of the Phoenix

HBP - Harry Potter and the Half Blood Prince

DH - Harry Potter and the Deathly Hallows 


\section{Introduction}

The Harry Potter fantasy series, written by J.K. Rowling, consists of seven books published in the span of nine years. The novels follow their title character Harry Potter, who at the age of eleven discovers the true cause of his parents' death, as well as the fact that he is a wizard made famous for his survival of a killing curse. Harry is a young boy who must face adult concerns and situations while maneuvering his way through adolescence. He deals with loss, survival, and independence; all in the name of defeating evil and saving his entire race. Balancing the fate of the wizarding world is quite the feat for a boy, who throughout the books is still in school acquiring the magical knowledge needed to defeat evil. This focus on independence and Harry's own need to discover and fight alone on his own terms diminishes the role or need of a mother figure, or any familial ties and therefore, follows a mixture of quest narrative, coming of age story and fantasy literature. Rowling choses to kill her hero's mother before the action of her story begins; therefore, it is surprising that she states: "mother love is hugely important in the books" and that a mother's love for her child is a "form of love that doesn't get explored as much as it should given that it's [...] so formative in everyone's life for good or for ill" (Rowling, "The Women”). Rowling loses her own mother during the course of writing the first novel and she admits this greatly affected her writing (Rowling, "The Women"). Rowling is well known for her own 'rags to riches' story. As a single mother, she struggled to make ends 
meet and was writing Harry Potter and the Philosopher's Stone, the first book in the series, while on welfare in England. ${ }^{1}$

Rowling is working within the genre of fantasy literature, yet she recognizes familial relationships as formative and important. Traditionally, fantasy literature supports independence and breaking of all ties, as Harry seems to do throughout the novels. According to Orson Scott Card, fantasy literature:

is about [the] 'romantic hero...going through the adolescent phase of human life.' This hero is 'unconnected.' He belongs to no community; he is wandering from place to place, doing good (as he sees it), but then moving on. This is the life of the adolescent, full of passion, intensity, magic, and infinite possibility, but lacking responsibility. (MacRae 1-2)

Card's idea is played out in the work of authors such as JR Tolkein, in his Lord of the Rings series and CS Lewis' The Chronicles of Narnia series, where there are no mothers. The genre of fantasy literature focuses on the hero's separation and independence from familial ties, especially a mother whose love can coddle. Fantasy genre's desire for the solitary hero is maintained in the series, yet Rowling forces her readers to delve into the different relationships of mother and child and the intense love a mother offers. Because of the Harry Potter series' attention on motherly love and the mother-child relationship, fantasy literature's traditional focus on the adolescent's independence is shifted.

\footnotetext{
${ }^{1}$ Harry Potter and the Philosopher's Stone is the original title of the novel. The title was changed for the U.S. market to Harry Potter and the Sorcerer's Stone.
} 
There is a growing body of critical work on the Harry Potter series, but no critical work takes the same psychoanalytic approach to mothers and their offspring in the novels, as does the current thesis. There are some articles and books written on the topics of gender, parenting/family and feminism. The article "Harry Potter, Radical Feminism and the Power of Love" speaks about Rowling's depiction of love resonating with radical feminism (Smith 87). Love is a force of good, used for protection and expressed in many different ways by Harry; love and compassion triumphs "over selfishness and ambition" in the series (91). As psychoanalysis is the viewing lens for my thesis, I would first like to briefly introduce the work of Sigmund Freud, where arguably all psychoanalysis stems. His work focuses on ones' linear development into adulthood where there is no fluidity, only stages to progress through. Sexuality is the driving force of a child's development according to Freud. The stages are oral, anal, phallic, latency (which is an in-between stage), and genital (which starts at puberty). The oral stage is "dominated by the pleasures and forms of significance made available by the mouth" (Russon 37). Feeding, sucking of fingers, taking any outside object and bringing it 'within' denotes the oral stage. This stage "emphasizes incorporation and bonding" (38). The anal stage is a toddler's attempt to declare his independence and separation from others (38). The phallic stage is where a child becomes aware of the physical and gender differences between a boy and girl. Also, for the male the Oedipus Complex enters in this stage. With the final stage, the genital stage, beginning at puberty, the adolescent utilizes lessons learned during the previous stages and direct his or 
her sexual urges onto opposite sex peers, with the primary focus on pleasure of the genitals. Ideally, Freud's theory of human development takes one from infancy into adolescence on a linear track; deviations from this, as in regressing into previous stages, result in neurosis and other problems. Klein takes the potential within Freud for non-linear development and exploits it to make it a primary characteristic of object-relations. Freud's theory does not lend itself to the reading of the Harry Potter series where Rowling represents non-linear fragments of a whole psyche.

The present thesis takes a psychoanalytic approach in analyzing the mother and child relationship as parts of one whole psyche, not individuals, and uses the work of Melanie Klein as its platform and language. Klein's base is object-relations theory, which states the object is both real others in one's world and one's internalized images of others. Object relationships are initially formed during early interactions with primary care givers. For the purpose of the current thesis, we shall say that the mother is the primary care giver. The "infant's original state is one of fusion with the mother who satisfies its need for warmth, food, and protection" (Doane 41). Object-relation theorists "stress that the self is born in relationship; separateness can only be established by a sense of relatedness to and difference from another" (Doane 42). Rowling stresses the fact that Harry is a deeply loved and cared for child during his first year of life, which is a very formative and developmental time. Children who are taken away from their primary care givers at birth do not form object relationships. Voldemort 
is a prime example in the novels and Harry's antithesis in every way, for he is born and raised until the age of twelve in an orphanage.

Kleinian theory takes object-relations a step further. Melanie Klein separates the infant's life into positions, not stages, as does Freud, to signify that positions "[apply] to modes of psychic functioning which last all through life" (Roth 33). Stages indicate a passage from one level to the next with a beginning and an end, while positions are fluid. Klein's positions, which "remain throughout [life as] the two elemental structures of emotional life," are the paranoid-schizoid position and depressive position, which have their origin in early childhood (Roth 33). In the paranoid-schizoid position the infant divides his perception of his experiences into two categories in such a way as to minimize his anxieties. He divides his world into 'good,' which he attempts to possess and to be, and 'bad,' which he tries to get rid of and locate outside himself, in his objects. (Roth 36)

The infant creates this polarized world through "splitting and projection. Splitting refers to the way the infant (and, later in development, the child and the adult) splits his picture of his object (one mother) into two felt-to-be-completely-different objects: a good one, and a bad one" (Roth 36 ). Splitting and projecting is done unconsciously, a phantasy, "in the mind of the subject...he splits the qualities of the single object and divides them between two or more objects" (36). In this stage, the good object "is loved not just because it feeds but because it inspires and is felt to return the infant's love" (41). The bad object contains such terrifying qualities "that the good mother must be experienced as ideal. Idealization then, is 
a normal and necessary stage in early infant development. It enables the good object to be taken in and installed in the infant's ego and protected from his attacks" (40). Splitting is two-fold because the infant also splits off his own qualities (ego), good and bad, and projects them upon his object. Projection "refers to the way certain qualities, characteristics or feelings which belong to originally the self, are disowned by the ego and attributed to someone else" (Roth 38).

The splitting of the mother is healed in the depressive position. An infant reaches the depressive position by "perceiving the mother as a whole person" (Doane 9). During this "reparation," there are "expressions of genuine love and regret, which develops....along with a deep gratitude for the goodness the child [receives] from the mother" (10). The object, that is the mother, becomes real and whole through an increase in love and a "greater trust in one's capacity to love" (10).

Rowling's portrayal of the mother-child relationship radically modifies Freud's theory of human development where the child moves through a series of stages into adulthood. Instead, one moves fluidly into and out of positions, which last throughout life as per Klein. I argue the mothers and their relationship with their offspring represent fragments of a whole complicated psyche. The characters are not analyzed as individuals, but instead as pieces, sometimes multiple pieces, of a whole psyche. When these characters and novels are taken together, a whole, multi-faceted "person" comes into view. Rowling depicts both 'good' and 'bad' mothers, and children who characterize different positions 
according to Klein. Although the series suggests a developmental arc, a coming of age story within fantasy literature, there is no linear progression; instead, there are disruptive positions without development.

The thesis utilizes Melanie Klein's theory along with other object-relation theorists who expand upon Klein such as Meira Likierman and Janice Doane as well as others. There are two chapters to this thesis. I found the most evident split to be between the 'good' mother and the 'bad' mother. Chapter one examines the 'good' mothers: Lily Potter (the idealized, ultimate good), Molly Weasley (the real, good enough mother) and Narcissa Molfoy (the "evil" mother). Chapter two will analyze the 'bad' mothers: Mrs. Black and Fridwulfa. Their offspring are Sirius and Hagrid respectively. These two sons express the depressive position without much, if any, linear development. 


\section{Chapter One: The 'Good' Mother}

Rowling's mother-child relationships showcase different parts of a whole with no linear progression. Melanie Klein states that a child splits his or her image of the mother into two "felt-to-be completely-different objects: a good one, and a bad one" (Roth 36). This chapter analyzes the 'good' mother according to Klein's theory. I explore the perfect idealized mother Lily Potter and her son Harry, who I argue does not grow beyond the paranoid-schizoid position. Molly Weasley is the 'good enough mother.' She is the most complete psyche represented in the novels; an integration of both good and bad. And there is Mrs. Malfoy who reaches beyond Klein's theory for her complexity.

\section{Lily Potter: the Idealized Mother}

Lily Potter is the perfect ideal mother. She is untouchable, unmitigated good. She is a benchmark comparison no real mother can reach; she is also Harry's projection; and she is dead for the start of the novels. Klein "assumes the very young infant to have rudimentary although unintegrated ego, that attempts to deal with experiences, particularly anxiety, by using phantasies of splitting, projection and introjection" (Spillius 63). Harry projects all that is good and pure

onto his mother and he splits off any potentially bad qualities and displaces them. "Idealization is none other than the result of defensive exaggeration of the object's goodness; [...] it is bound up with the splitting of the object" (Likierman 96). The bad object contains such frightening qualities "that the good mother 
must be experienced as ideal. Idealization then, is a normal and necessary stage in early infant development" (Roth 40). Harry, having only lived with his mother to the age of one, never progresses past the idealization of a perfect mother who cannot exist but who loved him fully. This position is the paranoid-schizoid position where it is normal and necessary to view the mother as ideal.

The paranoid-schizoid position plays an intricate role throughout life; "[t]he chief characteristic [...] is the splitting of both self and object into good and bad, with at first little or no integration between them" (Spillius 63). The principal task of the paranoid-schizoid position is to "make and maintain a separation between love and hate and 'good' and 'bad' aspects of itself and its object. This division or binary split protects the ego from being overwhelmed by anxiety and allows it to hold onto a 'good' self and 'good' object" (71). This then creates a platform for integration of the 'good' and 'bad' object into one whole object. But I will show that this does not occur for Harry Potter. Harry preserves the good object throughout his existence and never integrates the bad. Since Lily is dead from the outset of the novels, she remains perfect because she no longer exists; thus Harry cannot fuse his split mother into one whole object. If Harry cannot fuse his split mother and views her only as perfect - as is needed in the paranoid-schizoid position - Harry, as the hero of the novels, does not progress and is instead a fragment of the whole (as is his mother).

Lily Potter's great motherly act, or culmination of her perfection, is her ultimate sacrifice. Lily dies protecting her only child. Lily's sacrifice, due to her immense love for her son, forms a protection for Harry, which is a constant 
theme throughout the novels emphasizing the importance of a mother's role. Lily faces death and pleads with her murderer, "[n]ot Harry! Not Harry! Please - l'll do anything-" (PA 239). She refuses to stop shielding her son and in turn she is killed. Lily's death infuses Harry with her love; it runs through his veins.

Dumbledore tells a young Harry that "'to have been loved so deeply, even though the person who loves us is gone, will give us some protection forever"' (SS 299). Harry lives and survives because of his mother's love. He remembers very little of his mother and still yearns for her love, because in Harry's projection of his mother the love she provides is nothing less than flawless. When staring into a mirror that shows a person their deepest desires Harry sees his parents and "[h]e has a powerful kind of ache inside him, half joy, half terrible sadness" (SS 202). Dumbledore tells Harry his mother had a choice; she did not have to die for her son, but she was brave and stood between death and her child (HBP 262).

Having only a projection of a perfect mother leaves Harry desperately searching for traces of her to prove her existence; therefore, when he finds a handwritten note by Lily his extremities go numb and there is an eruption of joy and grief within him (DH 181). He reads and rereads the letter and when he can no longer extract anymore meaning he notices his mother makes her g's the same way he does and he "[searches] through the letter for every one of them, and each [feels] like a friendly wave glimpsed from behind the veil" (DH 181). For Harry this is "proof that Lily Potter had lived, really lived, that her warm hand had once moved across this parchment, tracing ink into these letters, these words, words about him, Harry, her son" (DH 181). This letter represents and proves 
that Lily is more than Harry's projection of a mother; she was at one point flesh and blood caring for a son she loved dearly.

This contact of a real mother for Harry is exhilarating, yet at the same time there is a constant distance because Lily is "behind the veil" (DH 181). J. K. Rowling uses the "veil" both physically and metaphorically in the series. Harry encounters a physical "tattered black veil" suspended on "a stone archway that [looks] ancient, cracked and crumbling" (OP 773). Harry is drawn toward this archway and hears whispering and murmuring (OP 773). The veil constantly flutters even though there is no wind, as if "someone had just passed through it" (OP 773). Sirius Black is later hit by a killing curse and "[falls] through the ancient doorway and [disappears] behind the veil" (OP 806). Metaphorically this veil represents the division between the living and the dead. Harry can physically hear the whispers and murmurs; maybe because he has lost loved ones. He feels a connection and wants to be joined with them. This veil helps uphold Lily's perfection.

The most powerful representation of Harry's projection of his mother comes in the last novel of the series. There is a mirror image between mother and son. Harry uses a resurrection stone to summon his loved ones to his side. They are a manifestation, "neither ghost nor flesh" and Lily smiles widely at Harry with "her green eyes, so like his, [searching] his face hungrily, as though she would never be able to look at him enough" (DH 698-9). Harry cannot speak and his green eyes, carbon copies of hers, "[feast] on her, and he [thinks] that he would like to stand and look at her forever, and that would be enough" (DH 699). 
The reader is privy to Harry's thoughts while Lily's want to look at her son is Harry's projection; his own desire for his mother to adore and admire him, as he is she. As per The New Dictionary of Kleinian Thought:

The bad object is not only kept apart from the good one but its very existence is denied, as is the whole situation of frustration and the bad feelings (pain) to which frustration gives rise. This is bound up with denial of psychic reality... possible only through strong feelings of omnipotence. (Spillius 72)

Lily Potter is no longer alive and Harry craves for her perfect love. There is absolutely no 'bad' in his mother as this section of the thesis showcases. She is simply pure and 'good' with no progression or integrating process for Harry.

Lily remains a God-like mother throughout the novels. Her wonderful qualities are not just creations formed by her beloved son; they stand in reality and in the collective minds of others as accurate representations; this only solidifies Harry's projection of her perfection. At the outset Lily sacrifices her own life to spare her child's. The reader soon learns that through her childhood and teenage years Lily was intelligent, brave and loyal. She encounters moments where she could have been vindictive, but she refuses. For example, Lily treats her older sister Petunia with love and care even though, out of pure jealousy, Petunia calls Lily a "freak" (a term and sentiment Petunia carries with her for life) (DH 669). Also, Lily befriends Severus Snape, an awkward boy. Lily remains friends with Snape and stands up for him until he insults her in a moment of shame and Lily, knowing Snape is choosing a path of Dark Magic and evil, ends 
the friendship (DH 676). Lily is a person who quite literally fights for what she believes in. Others speak fondly of Lily. An old Professor reminisces, "Lily Evans. One of the brightest I ever taught. Vivacious you know. Charming girl. Very cheeky answers I used to get back too"' (HBP 69-70). ${ }^{2}$

Klein's psychoanalytic theory revolves around the mother, which is a stark "contrast to the patriarchalism of orthodox Freudian theory and practice" and she is generally uninterested in the father's role (Sayers 26). But yet Klein reasoned that all of the infant's experiences leave traces in its psyche, and that such traces accumulate to the point at which they gather substance and assume more stable, identifiable forms. Since experiences are necessarily transmitted to the infant via the agency of a live human object, they are absorbed by its psyche in a highly anthropomorphic manner...[t]he early psyche is thus populated with beings who continue to represent dynamically what the infant has known in its interactions thus far in its life. (Likiernan 12)

It is then safe to assume that if the father is present, interactions are then absorbed into the child's psyche. Therefore, it is relevant to speak of Harry's father James and other father figures for Harry. While Lily's perfect mother status is upheld, James' is not. James is killed the same night as Harry's mother trying to protect his family from Lord Voldemort. James is a character who contains a more complete psyche - integrated for Harry as both 'good' and 'bad.' James Potter was a source of comfort and inspiration for Harry in his early years at

${ }^{2}$ Evans is Lily's maiden name. 
Hogwarts, "[w]henever someone [tells Harry he is] like James he [glows] with pride inside" (OP 653-4). But Harry's father was every bit as arrogant as Snape always claimed and this makes Harry feel "cold and miserable at the thought of" James $(650,654)$. This discovery nags Harry and makes him question the kind of man his father was. Harry is disappointed, yet at the same time, grounded by this discovery. James is not perfect, and that allows Harry to view his father as real and whole. Harry is so disturbed by his findings he questions his father's best friends Lupin and Sirius who attempt to explain James' behavior. Sirius states: "'your father was the best friend I ever had, and he was a good person. A lot of people are idiots at the age of fifteen. He grew out of it"' (OP 671). This teenage version of James grows and matures before becoming Harry's father. Harry eventually realizes and comes to terms with this fact, reaching the depressive position in his relationship with his father where reparation takes place. Harry's split image of his father becomes whole and James is a 'good enough' father with both 'good' and 'bad' qualities. "[D]evelopment is essentially a move from fragmentation to integration ...the mind's move towards integration is essential for growth, for it creates a composite identity made up of self-aspects that are gathered over time into a more inclusive and stable identity" (Likierman 89, 90). Harry never faces such feelings about his mother; he never has the need to question her goodness, and he never seeks out others' opinions to integrate her. The integration of his father is the only progression for the title character. But Harry remains inert with his idealized mother. 
Sirius Black and Professor Albus Dumbledore serve as similar father figures for Harry. Sirius Black, Harry's godfather, is a mixture of father and brother to Harry. Sirius is a source of irreplaceable advice, comfort and guidance for Harry. But at the same time Sirius does not fully mature into adulthood and he is rash and embittered. Sirius provides friendship for Harry more than structured discipline that a parent must uphold. Harry recognizes this when Sirius wishes to visit him at Hogwarts. Sirius does not realize the danger and consequences. Harry must tell him "I just don't want you chucked back to Azkaban!"' (OP 305). ${ }^{3}$ Sirius' response to this is not that of a responsible, reasonable adult whose first concern is his godson; instead he tells Harry "'[y]ou're less like your father than I thought $[\ldots]$ the risk would've been what made it fun for James'” (305). This causes tension in their relationship. Sirius' disregard for safety and need for freedom and excitement makes him less than stable for Harry.

Dumbledore is the man who watches and protects Harry. Harry respects and admires Dumbledore and they maintain a mentor-mentee relationship. Dumbledore is known as the best and brightest wizard of their time and Harry reveres him as such. Harry believes, due to their conversations revolving around him, that he knows and fully trusts Dumbledore; the man can do no wrong. But, with the death of Dumbledore, Harry learns of Dumbledore's past where he dabbled in Dark Magic wanting to control the muggle population and get rid of

${ }^{3}$ Azkaban is the wizarding prison guarded by beings called Dementors that drain all happiness from a person. 
those who might stand in the way. ${ }^{4}$ This occurs during Dumbledore's later teen years with the influence of a friend who continues down the dark path.

Dumbledore acknowledges these errors and devotes his life to a better cause. This experience teaches Dumbledore he cannot be in a position of great power. Dumbledore has limitations. He is a man like any other. Harry comes to realize this fact as Dumbledore essentially tells Harry: 'you are the better man' (DH 720).

Lily remains the idealized loving mother. She does not fall from grace in Harry's eyes as does his father and father figures. There is no moment of discovery for Harry with his mother that leaves him longing for naivety and bliss. Lily is filled with goodness that does not deplete Harry or make him "overly dependent on [the] idealized object," but instead makes him stronger, and he believes he is capable of making the same kind of sacrifice as his mother (Roth 39). This healthy ideal is preserved by the psyche as its most important life resource and is viewed as a source of hope (Likierman 96). When Harry is prepared to sacrifice his own life for the wizarding world, he summons his loved ones to his side, Sirius, James and Lily. They are ghost like, "[a part] of [him]" (DH 700). These are the people who provide him with love, which he internalizes after their death. But at the moment when Harry is ready to step forward and meet death, he "[looks] at his mother" and tells her "quietly [...] [s]tay close to me" (700). It is the relationship with his perfect mother that Harry cherishes above all else. She is the one who will protect and give him strength; he needs her to be near.

\footnotetext{
${ }^{4}$ Muggle is a person born with no magical powers.
} 
II. Molly Weasley: the Real, Whole Mother

From the idealized mother who cannot be touched, we shift our focus to the real, 'whole mother' in the series, Molly Weasley. Klein's mother, as per From Klein to Kristeva: Psychoanalytic Feminism and the Search for the "good Enough" Mother, "is wonderfully difficult to place; she is both inside and outside, both male and female. This mother, whether imagined as ideal or destructive, is not "really" good or evil: she is a fluid construction of the child's desires and anxieties" (Doane 16). This statement rightfully describes the motherhood for Mrs. Weasley. In an interview J.K. Rowling says, Molly "will mother the whole world if she can" (Rowling, "The Women"). Molly is a mother to seven - six boys and one girl. She displays several distinct characteristics that make her a 'good enough' and integrated mother. She raises her children with a stern hand, loves completely, and worries and protects with every fiber of her being. But being a 'whole mother' also means being an annoyance to the children who sometimes do not recognize the amount of love and care she provides each one. Molly is an integration of both the 'good' and the 'bad' simultaneously. She encompasses multiple pieces of the whole psyche represented when viewing all characters together to form one complete psyche.

Mrs. Weasley protects, sometimes overprotects, her children. She owns a magical grandfather clock with nine golden hands, $[\ldots]$ each of them engraved with one of the Weasley family's names. There [are] no numerals around the face, but descriptions of where each family member might be. 'Home,' 'school,' and 'work' [are] 
there, but there [is] also 'traveling,' 'lost,' 'hospital,' 'prison,' and in the position where the number twelve would be on a normal clock, 'mortal peril.' (GF 151)

She owns this clock for her own peace of mind and comfort. Molly also draws a strict line between her children that are adults at the age of seventeen and those that are still in school and the responsibility of an adult (OP 89). She tries to keep her children unaware of their immediate danger in order to keep them innocent, young, and carefree in the trying times. "You are too young to know the truth of adults,"' she once says to Harry (OP 87). Her nature is to love wholly and with that comes a protective instinct of which she cannot let go. She attempts to shelter her twin boys from excess information they do not need to know; but Molly's husband reminds her "they are of age"(OP 91). She cuts him off, reminding him that the twins are still in school, but legally they are adults who can make their own decisions (OP 91). Nancy Chodorow states in her book Reproduction of Mothering:

[A mother] needs to know both when her child is ready to distance itself and to initiate demands for care, and when it is feeling unable to be distant or separate. This transition can be very difficult because children $[\ldots]$ may one minute sense themselves merged with the mother (and require complete anticipatory understanding of their needs), and the next, experience themselves as separate and her as dangerous (if she knows their needs in advance). The mother is caught between engaging in "maternal overprotection" (maintaing primary identification and 
overdependence too long) and engaging in "maternal deprivation" (making premature demands on her infant's instrumentality). (Doane 35-6)

This is a precocious balance Molly attempts to navigate, although she leans on the side of "maternal overprotection" as much as she can. Molly does not want to let her children out from beneath her protective wing. She wants to keep them away from the danger as she does with her youngest, Ginny.

Molly's insatiable need to protect leads to badgering and over compensation. Molly reprimands her children for leaving in the middle of the night without her knowledge and stealing the flying car, screaming: "[c]ar gone—could have crashed—out of my mind with worry—did you care?—never[...] [y]ou could have died, you could have been seen, you could have lost your father his job-"' (CS 33). According to her children, Molly is an irritating, over exaggerating mother whose rant "[seems] to go on for hours" as she shouts "herself hoarse" (33). Molly's worry extends past her own offspring and encompasses Harry as well. She sheds tears over his safety and well-being. She embraces Harry during his times of need. Harry has "no memory of ever being hugged like this, as though by a mother" (GF 714). Molly's worry reaches new heights with the return of Lord Voldemort and the Order of the Phoenix. ${ }^{5}$ She cries, "[h]alf the f-f-family's in the order, it'll b-b-be a miracle if we all come through this..." (OP 177). Every hand on her magical grandfather clock points to mortal peril during this time and

\footnotetext{
${ }^{5}$ Lord Voldemort is a dark, evil wizard who enlists followers to help him take over the magical world and rid the society of witches and wizards who are not fullblood (born of parents who come from a string of witches and wizards). The Order of the Phoenix is a group led by Dumbledore who fights Voldemort's rise to power.
} 
when Molly faces a boggart, a creature that takes on the shape of a person's greatest fears, it takes the shape of her different family members dead as well as Harry. Because Molly's greatest fear is losing her family, she pesters them and raises her voice in hopes to make them understand her unconditional love and need to know they are safe.

Ron, the sixth child, feels as though he is not loved by his mother and he projects this lack of caring and love onto his mother. Yet, this is not the reality. His mother loves and cares for him at all times, she is 'good enough'; but Ron does not recognize it. He feels he can never live up to the grand achievements of his older brothers. Ron feels the mother he has cannot love him and his mediocrity as much as his elder brothers and younger sister. An object with dark powers and the ability to look deep into Ron's heart states: "[l]east loved, always by the mother who craved a daughter...[s]econd best, always, eternally overshadowed"' (DH 375-6). This feeling is projected onto his mother; therefore, when Ron is shown love, and rewarded, he brushes it off, not recognizing his mother is providing him with the love and attention he feels he lacks. He is instead a bit annoyed by her actions of love. For example, Molly is overjoyed and proud of Ron for being chosen as a Prefect and she places her "arms tight around [his] neck," and kisses him "all over his face which [turns] a [bright] scarlet" (OP 163). ${ }^{6}$ He tries to push her away and says "'Mum...don't...Mum, get a grip,"' as his twin brothers snicker in the background (OP 163).

${ }^{6}$ A Prefect, as per http://harrypotter.wikia.com/wiki/Prefect, is a student at Hogwarts "who has been given extra authority and responsibilities by the Head of House or Headmaster or headmistress." 
Molly Weasley is a 'real,' grounded mother. She is 'good enough' because she loves all and protects while at the same time being an annoyance to her children. She is grounded in reality. Molly is not perfect as Lily Potter because she is alive and vibrant, living on a day-to-day basis, raising her children, and making mistakes. She loves beyond her own children encompassing Harry and showing him the love and protection of a 'real' and present mother.

\section{Narcissa Malfoy: ‘Good’ Mother Transcending Evil}

The Malfoy family members are aristocrats who believe themselves above all others and are aligned with Voldemort's belief of cleansing the magical race. They are evil and enemies to Harry Potter and the 'good guys.' Narcissa Malfoy, mother to Draco, is described as blonde, tall and slim, and "she would [be] nicelooking if she [wasn't] wearing a look that suggested there was a nasty smell under her nose" (GF 101). Narcissa's character is arrogant and cruel, and her actions toward others prove this. She is also the wife of a man who proves himself evil time and time again therefore, the reader automatically assumes she must be the same. Narcissa is a minor character in the novels, but she is an important and complicated mother. Her character is most revealed to the reader as a mother who protects fiercely with complete disregard to others. However, it seems her nastiness stems from protecting her son. She is truly a split character because she wholly loves and protects her son, yet to all others she is a hurtful and callous woman. 
Narcissa's appearances in the novels occur in conjunction with her son Draco Malfoy; her cruelty is displayed as a form of protecting her son. In a confrontation with Harry and his friends, antagonized by Draco, Narcissa states coldly "'[p]ut [your wands] away[...] [i]f you attack my son again, I shall ensure that it is the last thing you do"' (HBP 113). She threatens these children with complete disregard to consequences and fear. As Narcissa "smiles unpleasantly" she says she is certain Harry will meet Sirius in death before she reunites with her husband in prison (HBP 113). Narcissa ends the confrontation with a contemptuous glance at Hermione, calling her "scum" as she walks away (HBP 114).

Later in the series Narcissa's character is revealed as a loving and protecting mother. She places her own life in danger to try to help her son and keep him safe. She rightfully fears that her son is in danger, and she races to Severus Snape for help. Bellatrix, Narcissa's sister, attempts to stop her and Narcissa pulls out her wand threateningly. Bellatrix laughs and says: "Cissy, your own sister? You wouldn't-" Narcissa responds, "'[t]here is nothing I wouldn't do anymore!"' (HBP 21). Narcissa is a mother who is prepared to do what is necessary to protect her son. She begs Snape to help protect Draco (Snape is the only person she can turn to with her husband in prison). As "tears [slide] down her pale cheeks" she whispers "[m]y son...my only son"” (HBP 33). When Snape does not deny nor confirm Narcissa's suspicions that her son is on a suicide mission, she loses "what little self-restraint she still [possesses], standing up, she [staggers] to Snape and [seizes] the front of his robes [...] [with] [h]er 
face close to his, her tears falling onto his chest" (HBP 34). Bellatrix does not understand the love a mother has for her child because she ruthlessly states: " [y]ou should be proud![...] [i]f I had sons, I would be glad to give them up to the services of the Dark Lord!" and "Narcissa [gives] a little scream of despair" (HBP 35). Narcissa places herself as a mother before a follower of the powerful Lord Voldemort. She is desperate in her attempts to protect her son and puts her life at risk for even speaking of the danger. As a reader, one cannot help but feel sympathetic for this mother who is trying to protect her son, despite the fact that these actions can potentially adversely affect the 'good guys' and Harry.

With Narcissa, a complicated mother, the series slowly reaches beyond good and evil and changes the reader's perception of Narcissa as an evil woman. Narcissa echoes the actions of Lily Potter at the end of the series. J.K. Rowling states:

it is a quite conscious echo of what Lily did, right at the start of the story, at the very end of the story. At the end of the story, Harry lies pretending to be dead on the ground and it's a mother who saves him again because she is trying to get to her own son...so that was closing a circle; [Harry] was saved there by Lily, saved there by Narcissa. (Rowling "The Women") Narcissa - a dedicated, but frightened follower of Lord Voldemort - lies to her master (who has been scheming from her home) in order to seek out her son. She leans over Harry Potter, knowing Harry is truly alive, and asks: "[i]s Draco alive? Is he in the castle?'” (DH 726). Harry barely breathes 'yes' and Narcissa declares "'[h]e is dead!" (726). Harry quickly understands why Narcissa lies. She 
knows this is "the only way she would be permitted to enter Hogwarts and find her son, as part of the conquering army. She no longer [cares] whether Voldemort [wins]" (726). With this fierce need to find and protect her own son, she also protects Harry from death. For Narcissa that is a by-product. Her only concern is Draco. Rowling depicts motherly love as a universal sentiment that transcends good and evil with Narcissa.

\section{Conclusion}

I have painted a picture of three very different 'good' mothers and their respective children in the Harry Potter novels. Lily Potter is perfect and idealized because she is not alive. Harry, having only lived with his mother to the age of one, is never able to experience anything but the paranoid-schizoid position where it is normal and necessary to view the mother as ideal. He lives with a projection of his mother as unmitigated good. He yearns for her love and despairs for any trace of her actual existence. Yet Lily always remains out of reach and behind the veil that upholds her perfection. While Harry's father James becomes real and whole, Lily remains perfect and the one person Harry needs by his side. On the other end of the spectrum, we have Molly Weasley who is alive, real and whole. She is the integration of both the 'good' and the 'bad.' She overprotects her children, worries over them profusely, annoys them, and finds room in her heart to love Harry; giving him the example of a real mother. Molly is rounded and complete because, to her children, she is one mother, one object, who posses all these facets. And there is Narcissa Malfoy who is a complicated 
mother. Narcissa's character is cruel to others, but she loves and protects her son wholly. Rowling forces the reader to look beyond good and evil and see Narcissa as a mother desperate to find her son and as a consequence mirroring Lily Potter's final motherly act. 


\section{Chapter Two: The 'Bad Mother'}

Chapter one of this thesis explored the 'good' mother. Rowling represents the idealized mother, Lily Potter, as a necessary experience and a splitting of the whole mother. Harry maintains his idealized mother because she no longer exists and his projection of her is perfection while the whole, real mother, Molly Weasley, loves and cares in the real world. These mothers are parts of a whole pieces of a complicated psyche that shows impulses toward a developmental arch, but is non-linear.

This chapter shifts its' focus to the 'bad' mother and the unresolved depressive position for the respective child. The characters of Mrs. Black and Sirius Black are explored as well as Rubeus Hagrid and his mother, Fridwulfa. I also explore Hagrid's nurturing maternal side toward dangerous creatures and beings as a reflection of his own relationship, or lack there of, with his giantess mother.

Klein's concept of the depressive position comes about with an infant's realization that he/she can lose its loved object due to the "mental grasp of experience and of the good object [being] partial and changeable"(Likierman 100). The loss of the loved object is generated by the awareness that the "ideal object of unlimited pleasure and satisfaction" does not exist, "[t]he whole mother initially represents a despoiled perfection and provokes sorrow and indignant rage in turn" (Likierman 101). This turn from partial, ideal mother, to whole mother is the start of the depressive position. This position is 
set out as both developmentally progressive and positive and, simultaneously, as a dangerous crisis point in which sets in motion ambivalence, a catastrophic sense of loss and also, psychotic anxieties and defenses, all of which need to be overcome. (Likierman 115) Ambivalence is "regarded as an insoluble hostility towards a disappointing, but none the less intensely needed and loved object" (121). Ambivalence is a "tormented state" where the object is needed, sought and loved, "yet strong resentment [means] that it [is] equally hated" (103). Without ambivalence, the depressive position could not exist. The individual can simply love and accept the object or hate and reject it (103).

Overcoming, as per Klein, must take place. Large-scale overcoming "is achieved when 'love for the real and the internalized objects and trust in them are well established', that is, when primitive ambivalence recedes, so that 'when the infant is able to feel that his mother will return, because his experience of regaining that loved object has proved this to him" (126). The mothers in this chapter do not prove themselves to be loving and trustworthy. They are unloving and damaged and their children are unable to overcome the ambivalence they feel toward their mother. Sirius never overcomes the resentment, while Hagrid attempts to channel that resentment. Overcoming is dependent upon "secure instating of the good object within [the] inner world; the process of mastering hate by love must be reached and corresponds to the secure establishing of the good object within the ego as a strong core" (123). The sons to these 'bad' mothers are incapable of reconciling their feelings for their mother; hatred prevails and 
thus they are unable to overcome the depressive position. These characters represent only a part of the whole psyche, one position in relation to the 'bad' mother. The depressive position, like all of Klein's positions, can affect anyone at any age. But with these characters, it seems to stem from early childhood where love and trust is built.

I. Mrs. Black: the 'Bad' Mother

Mrs. Black, mother to Sirius Black, is introduced in book five of the series, Harry Potter and the Order of the Phoenix, through a life-size portrait hanging in her ruined home. She is not a "loving and undamaged mother" providing her children with "repeated and reassuring contacts" which "gradually [corrects the natural] internal distortion..." (127). Instead she shuns her oldest child, Sirius, and allows him to leave her home in hatred. She is the strongest representation of a 'bad' mother in the series.

The state of the denigrating and depressing Black house is an outward representation of the damaged mother within it. Dumbledore and Harry state how much Sirius hates the Black house he is locked in. It is a constant reminder of the damaged mother with which he grew up (OP 834). Mrs. Black is a mother who, according to Gustafson's Unbecoming Mothers: The Social Production of Maternal Absence, "ignores her child's need for love, caring and nurturance" (28). Mrs. Black's portrait, hiding behind a "moth eaten velvet curtain," has the power to speak (like others in the wizarding world) and when Mrs. Black speaks it is a "horrible, earsplitting, bloodcurdling screech" (OP 60; 77). Sirius shouts for 
her to "'shut up"' and as he comes into her view she bellows: "[y]oooou!' ...her eyes popping at the sight of the man. 'Blood traitor, abomination, shame of my flesh!"' (OP 78). Mrs. Black deems her son unworthy and a shame to the family name. She disowns Sirius and erases him from the family tree tapestry hanging in the Black drawing room. In Attachment and Loss: Volume II Separation Anxiety and Anger, John Bowlby says a mother might be "physically present but 'emotionally absent [...] Although present in body a mother may be unresponsive to her child's desire for mothering" (23). Hagrid's mother, as explored later in this chapter, is unresponsive, but Mrs. Black is actively damaging to her child; she responds with negativity and hatred.

Sirius states that his mother has no heart in a retort to his house-elf Kreacher (OP 109). Kreacher is an indentured servant. Bound by magic, houseelves cannot deny their master. House-elves also absorb their master's beliefs, do not have ideas or thoughts of their own, are extremely loyal in every respect, and keep their master's secrets. Therefore, when Kreacher speaks negatively about Sirius, there is no doubt these words come from Mrs. Black whom Kreacher reveres. Kreacher states: "'[Sirius] was a nasty ungrateful swine who broke his mother's heart-“" (OP 109). Kreacher continues to say, "'how [Mrs. Black] hated [Sirius], what a disappointment he was"..... "she swore he was no son of hers"' (OP 109; 110). This mother completely detaches herself from her son because he does not hold the same beliefs. She does not respect her child for who he is. 
According to Klein "[d]epression is typically preceded by [a] rebellious state toward [the] resented object" (Likierman 113). Sirius is a rebellious rule breaker by nature. He runs away from home at the age of sixteen because he'd "had enough" and spends summers with the Potters' where "they sort of [adopt him] as a second son" (OP 103, 111). Sirius never returns to the Black house until he is forced to hide out there a decade later. While at Hogwarts he, James, and others break school and wizarding rules. They become unregistered animagus and sneak out of school at each full moon to be with their werewolf best friend. ${ }^{7}$ Sirius also breaks out of Azakaban where he is falsely imprisoned and must remain in hiding because his name cannot be cleared. But as Dumbledore says: "Sirius was a brave, clever, and energetic man, and such men are not usually content to sit at home in hiding'" (OP 825). Therefore, Sirius takes risks and finds it fun without considering the consequences (OP 305).

Sirius' character is killed without resolving his ambivalence toward his mother. His existence in the novels exemplifies only the depressive position. He cannot "accept and forgive his object, nor reject and relinquish it"; he is an imprisoned depressive individual (Likierman 103). Hatred is a feeling just as love is; rejecting an object means having no feelings for it. Rowling uses adjectives such as 'bitterly' and Sirius laughs 'sourly' as he remembers or tells of his mother (OP 113). Sirius does not move past the depressive position and unfortunately dies without letting go of the hatred for his damaged mother.

\footnotetext{
An animagus is a person who can completely transform into an animal and take on the animal's characteristics. Each person with this capability must register with the Ministry of Magic.
} 
The Harry Potter series departs from the archetypal quest/coming of age narrative with its focus on the mother and the unresolved issues with the child. Rowling's characters represent complicated fragments of a whole psyche. A linear coming of age story is not represented in these novels. Sirius is the prime example of a character with unresolved issues. Rowling kills Sirius leaving him in the depressive position with a 'bad' mother who is also dead from the outset of the novels so she can be nothing more or less than the 'bad' mother who intentionally damages her child. There is no development for either character, which points toward no forward movement.

\section{Hagrid and the Absent Mother}

Hagrid cannot remember his giantess mother, Fridwulfa, because she leaves him at the age of three. Hagrid states to friends of her passing with a shrug that "'[s]he wasn' really the maternal sort'", nor was she a "'great mother"” (GF 428; OP 434). Hagrid acknowledges it is not in the nature of giants to be maternal nurturers (OP 427). In fact, in the wizarding world, giants are isolated and known to be a violent and uncivilized race. Fridwulfa is an unresponsive mother who rejects her child's need to be loved and nurtured. Klein envisions presence and love as acting "continually in the minutia of ordinary daily interactions between [the offspring] and its mother" (Likierman 126). But Hagrid's mother is only physically present during his first 3 years of life and emotionally absent. Daily interactions, i.e., nurturing, leads to a needed normalcy. Klein believes the crucial role of the mother is to provide normality for the child. 
The normality of the child is defined as " [t]he extent to which external reality is able to disprove anxieties and sorrow relating to the internal reality"' (Likierman 126). Hagrid is not "able to establish securely a good, loved object in his inner world"; therefore, he cannot overcome the depressive position (Likierman 128). Hagrid's external world consists of an unresponsive mother and a father who did his best in raising a son alone.

Parallel to Klein's view, Nancy Chodorow, a feminist object-relations theorist, claims that viewing an infant's needs as unproblematic leads to the "description of a mother 'good enough' to address [its] needs" (Doane 2). To produce well-adjusted children the mother needs to be good enough and present. Chodorow states, "the infant's earliest relational experience with its mother structures its later development. The infant's original state is one of fusion with the mother who satisfies its needs for warmth, food, and protection" (Doane 41). According to John Bowlby's book Attachment and Loss Volume II, "[s]eparation from [the] mother figure...leads to sadness, anger, and subsequent anxiety in children aged two years and over...separation from mother figure is in itself a key variable in determining a child's emotional state and behaviour" (22). Hagrid is left with only his father from the age of two to eleven - a father who is mentioned only briefly in the novels, but who is Hagrid's only nurturer and helps provide Hagrid with his true sense of self. As the wizarding world discovers the unspoken truth that Hagrid is half-giant they clamor for his resignation and Hagrid shuts himself up from the world. Dumbledore, his pseudo-father, urges him to 'get back out there.' Hagrid remembers his real father's teachings and says: "I 
am what I am, an' I'm not ashamed. 'Never be ashamed,' my ol' dad used ter say, 'there's some who'll hold it against you, but they're not worth botherin' with.' An' he was right"' (GF 456). Hagrid feels shame because his mother is a giant, a shunned race, making him half-giant and he is hurt because she leaves him. A mother who is not good enough and abandons her child leaves a scar. Hagrid reaches out and forms bonds with unlikely candidates as a way of dealing with the internal stress. This manifestation of Hagrid's internal distress is explored in the next section of this chapter.

\section{Hagrid as a Maternal Figure}

A paper titled "The nature and the function of phantasy" written and presented by Susan Isaacs, a Kleinian devotee, states:

phanstasy involves imaginal, sensory and somatic states. In the face of painful need, the infantile body together with the wishing, instinctual psyche, produces a particular phantasy. Although it belongs in the normal awake functioning of the infant, phantasy is therefore, in a sense, a species of dream life. (Likierman 138)

Hagrid creates a phantasy with the dangerous creatures and half-brother he cares for in a maternal fashion in order to cope with the lack of mothering from his own mother. Klein believes objects are used to express phantasy and can be observed in child's play. "[T]he particular scenario of which phantasy is composed is always and specifically based on object relations, in which an object is either treated in a particular way, or else itself meting out a particular kind of 
treatment to the subject" (Likierman 140). For Hagrid, the objects are the dangerous creatures and later his half-brother and it helps him overcome the void he feels from the lack of a mother.

Hagrid literally becomes a mother to these objects. Hagrid refers to himself as "Mommy" to a dragon he fosters from a hatchling to a few weeks old (SS 236). Hagrid does not refer to himself as daddy as is gender appropriate; he is therefore giving greater importance to the role of the mother, which he believes is the role he must take on in order to properly care for and love his objects. Hagrid's mother essentially throws him away and the creatures Hagrid cares for are discarded by society because they are feared. Hagrid sees a parallel within himself and these dangerous creatures; each are feared and not loved. Hagrid needs to give these creatures what he himself lacks - a mother, which means a loving and protective bond. During Hagrid's lifetime he also cares for a giant spider and a hippogriff with ill regard to rules, the law, his other responsibilities or the consequences. Hagrid loses sight of what is rational when his compassion and need to protect a creature takes over. Hagrid ignores the possible hazards and consequences that come along with caring for these dangerous creatures, much like a mother who would sacrifice herself for her child. Hagrid does not see these creatures as damaging; instead he can nurture, love and care for them in a way he was deprived of.

Hagrid's maternal instinct reaches beyond dangerous creatures and encompasses his giant half-brother in an attempt to recreate the family unit he needs. Hagrid brings home and tries to care for and civilize his giant half-brother 
Grawp, who his mother also abandons; "'she don' seem ter have liked him much more'n she liked me'" Hagrid states (OP 691). Grawp is too small, only 16 feet, and what counts with giants is producing large children (OP 691). Giants are uncivilized, dangerous, violent and do not speak English. Despite the fact that Grawp does not want to go with Hagrid and Grawp is injuring Hagrid, Hagrid brings Grawp to his home. Hagrid feels as though he has no choice but to protect his half-brother who is being bullied by the other giants in the colony (690). Hagrid feels an immediate sense of obligation and love. Hagrid tells Harry and Hermione, "sounding close to tears": "I know if I jus' got him back... 'an'-an' taught him a few manners-l'd be able ter take him outside an' show ev'ryone he's harmless!'” (609-10). Giants are feared and known for their violent nature; therefore, this is quite the feat Hagrid is undertaking. Hagrid wants to nurture his half-brother as he does with dangerous creatures. Hagrid wishes to show outsiders that what they consider to be dangerous can be loved and not feared. Hagrid states "gloomily": "'[m]akes a diff'rence, havin' a decent family'... "Family. 'Whatever yeh say, blood's important..." (OP 564). Hagrid is deprived of a decent loving family. He creates a phantasy of becoming a mother himself in an attempt to fill the void.

Hagrid struggles to become the "ideal object of unlimited pleasure and satisfaction" via his phanstasy of being a mother figure to the dangerous creatures and his half-brother (Likierman 101). This is unattainable. But since Hagrid never experiences the 'ideal' or 'good enough' mother, only the bad and never present, he strives for perfection. Hagrid is the only character in the novels 
that experiences progression. With Rowling depicting Grawp as somewhat civilized and able to reciprocate a kind of love and respect there is movement toward reparation for Hagrid.

\section{Conclusion}

The characters analyzed and discussed in this chapter represent fragments of a whole psyche. There are impulses toward a developmental arc, which suggests a complex coming of age story, but there is no linearity.

Sirius and Hagrid are sons to 'bad' mothers and represent the depressive position. Mrs. Black does nothing for her child's need to overcome the internal "psychotic anxieties and defenses" that comes along with the depressive position (Likierman 115). She is present yet destructive as she outwardly abhors her son Sirius and disowns him. The depressive position cannot exist without ambivalence because the individual can simply "love and accept the object or hate and reject it" (103). Sirius does not reject/let go of his mother and that within itself shows his need/want for the mother he never experiences. Sirius is killed in the $5^{\text {th }}$ novel and is unable to overcome the depressive position. He is quite literally a piece of the whole with no progression.

Hagrid suffers abandonment by his mother who he recognizes has no maternal instincts because she is a giant and giants are known for their display of violence. This separation from his mother forms his "emotional state and behavior" (Bowlby 22). As a coping mechanism for his depressive position, Hagrid forms a phantasy and becomes a mother figure to dangerous creatures 
and beings (objects) that are discarded, just as he was as a child. Hagrid sees himself in those for whom he cares. Since he lacks the maternal love and protection, he feels a sense of obligation to provide it to the dangerous creatures that are rejected. With his half-brother Grawp, a sense of caring is reciprocated and Hagrid begins the reparation process. 


\section{Conclusion}

In a web chat conducted after of the release of Harry Potter and the Deathly Hallows, a fan posed the question: "[h]ow much does the fact that [V]oldemort was conceived under a love potion have to do with his [non-ability] to understand love[?] [l]s it more symbolic[?]" Rowling responds: "[i]t was a symbolic way of showing that he came from a loveless union - but of course, everything would have changed if Merope had survived and raised him herself and loved him." Merope is Voldemort's mother who dies at childbirth leaving Voldemort to be raised by an orphanage. With this answer, Rowling discloses once again the importance of a mother's love. One can infer from Rowling's answer that the lack of a mother's love causes Voldemort to become an evil man. On the other side you have the abundance of love that Harry receives from his mother protecting him from said evil. This places a mother and her love, or lack thereof, as a central theme and crux of Rowling's adventure.

Klein's theory is used in this thesis to help unravel the different representations of the mother and the relationship with the child. Rowling presents the ideal, the 'bad,' and the 'good' mother; as well as offspring who, show activity, but not linear activity, and represent the paranoid-schizoid or depressive positions.

The Harry Potter series does not follow the tradition of fantasy literature or quest narrative. In these genres it is the separation of the child from the mother or the absence of mothers that is significant. For example Percival; the title 
character leaves his mother at the start of the story to begin his journey and in the famous fantasy series Lord of the Rings, there are no mothers to be found. The Harry Potter series stress the role of the mother and her love, even though the hero embarks upon an independent journey. It is a coming of age story, yet there is no linear development. The novels present various positions in the different characters and their relationships with their mothers. It is vital not to view each character as a whole psyche but to take each individual character as pieces, sometimes multiple pieces, of a whole psyche, therefore together they are whole. In this conclusion I will reflect upon the insights revealed in this thesis through Klein's theory and also discuss the methodology's limitations.

Klein's object-relation based theory helps illustrate the characters of Lily and Harry Potter. As l've argued Lily Potter is the idealized mother in the series and Harry's projection. Harry projects all that is good and pure onto his mother and he splits off any potentially bad qualities and displaces them. The bad object contains such terrifying qualities "that the good mother must be experienced as ideal. Idealization then, is a normal and necessary stage in early infant development" (Roth 40). The splitting of the mother and viewing her as only 'good' takes place within the paranoid-schizoid position. Harry does not progress beyond this view. As is illustrated in chapter one of this thesis it is necessary for Harry to never reconcile the split, perfect mother. As Harry faces the fact that he too must sacrifice his own life he summons his mother's physical spirit to be near him. The all encompassing pure love and perfect mother give him strength. 
And again Harry is the representation of one piece of the whole, not a whole in and of himself.

Sirius Black and Hagrid are sons to the 'bad' mothers and represent the depressive position. Sirius' character does not resolve his ambivalence toward his mother. His existence in the novels exemplifies only the depressive position. He cannot "accept and forgive his object, nor reject and relinquish it"; he is an imprisoned depressive individual (Likierman 103). Rowling uses adjectives such as 'bitterly' and Sirius laughs 'sourly' as he remembers or tells of his mother (OP 113). Sirius does not move past the depressive position and unfortunately dies without letting go of the hatred for his damaged mother.

Unlike Sirius, Hagrid shows progression from the depressive position. Hagrid struggles to become the "ideal object of unlimited pleasure and satisfaction" via his phanstasy of being a mother figure to dangerous creatures and his half-brother (Likierman 101). This is in an attempt to fill the void he feels due to the mother who abandons him.

However there are limits to Klein's methodology and not all mothers and their offspring in the Harry Potter series fit the paradigm. For example Narcissa Malfoy is a cold, cruel woman who insults others and adopts her husband's evil ideology, but as a mother she loves her son wholly and does anything necessary to protect him. Narcissa inadvertently saves Harry's life just to reach her son. She mirrors Lily's act, but she is not an idealized mother. She represents a mother who is neither 'good' nor 'bad.' And it is clear Rowling is transcending good and evil with this character as a mother. 
There is also Petunia Dursley. She grows up jealous of her sister Lily and creates a hate towards the "freak", "it was Lily this and Lily that, [their parents] were proud of having a witch in the family!'” Petunia explains to Harry with a mix of distaste and envy (SS 56, DH 669). Rowling states on her site pottermore.com that: "Petunia[...] [is] forever embittered by the fact that her parents seemed to value her witch sister more than they valued her." Therefore, it is not surprising that Petunia loves her son overzealously and spoils him to no end. As a child he kicks and screams at her and as a teenager he manipulates and lies to get his way. Petunia raises a disrespectful, ill-mannered boy because she loves without disciplining and she is blinded to the truths of her son.

There is criticism of Harry Potter that states the characters are caricatures, which is a "representation [that] includes comic exaggeration in the description of the internal or external characteristic of a character and always refers to the individual" (Mikulan 290). This thesis contradicts this idea because it does not analyze the characters as individuals, but instead, through Klein's theory, views the mothers and their relationships with their children as pieces, sometimes multiple pieces, of a whole complicated psyche. When these characters are taken together, a whole, multi-faceted "person" comes into view. 
Arden, Heather and Kathry Lorenz. "The Harry Potter Stories and French Arthurian Romance." Arthuriana 13.2 (2003).

Bowlby, John. Attachment and Loss. Volume II Separation Anxiety and Anger. New York: Basic Books, 1969. Print.

Collins, Robert A. and Howard D. Pearce. The Scope of the Fanstatic-Theory, Technique, Major Authors: Selected Essays from the First International Conference on the Fantastic Literature and Film. Westport, Conn: Greenwood Press, 1985. Print.

Doane, Janice L, and Devon L. Hodges. From Klein to Kristeva: Psychoanalytic Feminism and the Search for the "Good Enough" Mother. Ann Arbor University of Michigan Press, 1992. Print.

Gustafson, L. Diana. Unbecoming Mothers: The Social Production of Maternal Absence. New York: Haworth Clinical Practice Press, 2005. Print.

Hinshelwood, R D, Susan Robinson, and Oscar Zarate. Introducing Melanie Klein. London: Totem Books, 2011. Print.

Likierman, Meira. Melanie Klein: Her Work in Context. London Continuum, 2011. Print.

Little, T E. The Fantasts: Studies in J.R.R. Tolkien, Lewis Carroll, Mervyn Peake, Nikolay Gogol, and Kenneth Grahame. Amersham, England: Avebury, 1984. Print.

Jackson, Rosemary. Fantasy: The Literature of Subversion. London: Routledge, 1988. Print.

Klein, Melanie. The Psycho Analysis of Children. New York: Humanities Press, 1969. Print.

MacRae, Cathi D. Presenting Young Adult Fantasy Fiction. New York: Twayne Publishers, 1998. Print.

Manlove, C N. The Impulse of Fantasy Literature. Kent, Ohio: Kent State University Press, 1983. Print. 
Mikulan, Krunoslav. "Harry Potter through the Focus of Feminist Literary Theory: Examples of (Un)Founded Criticism." Journal of International Social Research 2.9 (2009): 288-298. Print.

Mills, Jon. Rereading Freud: Psychoanalysis Through Philosophy. Albany: State University of New York Press, 2004. Print.

Rabkin, Eric S. The Fantastic in Literature. Princeton, N.J: Princeton University Press, 1976. Print.

---. Fantastic Worlds: Myths, Tales, and Stories. New York: Oxford University Press, 1979. Print.

Roth, Priscilla. "The Paraniodd-schiziod Position." Bronstein, Catalina. Kleinian Theory: A Contemporary Perspective. New York: Brunner-Routledge, 2002. 32-46. Print.

Rowling, J.K. "The Women of Harry Potter." Harry Potter and the Deathly Hallows Part 2. Dir. David Yates. Warner Bros Entertainment Inc. 2011. DVD.

---. Harry Potter and the Sorcerer's Stone (SS). New York: A.A. Levine Books, 1998. Print.

---. Harry Potter and the Chamber of Secrets (CS). New York: A.A. Levine Books, 1999. Print.

---. Harry Potter and the Prisoner of Azkaban (PA). New York: A.A. Levine Books, 1999. Print.

---. Harry Potter and the Goblet of Fire (GF). New York: A.A. Levine Books, 2000. Print.

---. Harry Potter and the Order of the Phoenix (OP). New York: A.A. Levine Books, 2003. Print.

---. Harry Potter and the Half Blood Prince (HBP). New York: A.A. Levine Books, 2005. Print.

---. Harry Potter and the Deathly Hallows (DH). New York: A.A. Levine Books, 2007. Print.

Sayers, Janet. "Melanie Klein, Psychoanalysis, and Feminism." Feminist Review 25 (1987): 22-37. Print. 
Smith, Anne Collins. "Harry Potter, Radical Feminism, and the Power of Love." Ed. Gregory Bassham. Ultimate Harry Potter and Philosophy. John Wiley \& Sons Inc. 2010: (80-93). Print.

Spillius, Elizabeth B, and R D. Hinshelwood. The New Dictionary of Kleinia Thought. Hove, East Sussex: Routledge, 2011. Web.

Tolkien, J R. R. The Monsters and the Critics: And Other Essays. London: HarperCollins, 1997. Print.

Whited, Lana A. The Ivory Tower and Harry Potter: Perspectives on a Literary Phenomenon. Columbia: University of Missouri Press, 2002. Web. 